\title{
A Psychoanalytical Note on Naming and Renaming
}

\author{
Byung-Wook Lee \\ Hanbit Mind Research Institute, Seoul, Korea
}

\section{작명(作名)과 개명(改名)에 대한 분석적 소고(小考)}

\author{
이 병 욱 \\ 힌빛마음연구소
}

\begin{abstract}
Naming is very important event in our lives because personal names are very meaningful in terms of their powerful influences on our everyday lives. We all begin to our lives with given names just after birth, and while we are growing up, the name naturally becomes to the major part of the ego. The attitude toward name also reflects the ego attitude positively or negatively, at times neurotic. Therefore all parents is very careful to make naming at their baby births. There is an old proverb that the tiger dies and leaves the leather, and the person dies and leaves name behind. This means that our names represent the human dignity, and emphasizes the importance of naming. But there were many persons tried to change their given names. They used the various pen names, stage names, nick names, pseudonyms, anonyms, alias, total or partial renaming. Their renaming behavior is likely to hide many various personal motivations. Their main motivations reveal the personal conflicts and identity problems. Those are the denial of familial origins, or the concealment of native lands, family romances, wishful rebirth fantasies, secondary gainings, dissatisfied self-images, or personal insecurities, self-protectiveness, lowered self-esteems, chronic inferiorities, preserved privacies. Renaming needs to be considerably decisive as well as the religious conversion. But I would like to conclude that the most powerful motivating forces of renaming are the identity crisis and intrafamilial conflicts.
\end{abstract}

Psychoanalysis 2016;27(4):123-132

KEY WORDS: Naming $\cdot$ Renaming $\cdot$ Identity $\cdot$ Conflict.

Received: September 9, 2016 Revised: October 1, 2016 Accepted: October 3, 2016

Address for correspondence: Byung-Wook Lee, MD

Hanbit Mind Research Institute, 316 Banpo-daero, Seocho-gu, Seoul 06509, Korea

Tel: +82-2-536-9775, E-mail: hanvitwooklee@naver.com

\section{서 론}

이름은 태어나서 죽을 때까지 그 운명을 함께 할 뿐만 아 니라 죽은 이후에까지 영원히 기억되는 유일한 개인적 자산 이다. 따라서 그 이름만 들어도 그 주인공의 전 인격체 및 그 가 살았던 삶 전체를 떠올리게 되는 것이다. 그만큼 이름은 그 사람을 대표하는 매우 중요한 상징인 동시에 개인적 삶의 지표인 셈이다. 따라서 특히 우리사회에서는 오래 전부터 작 명을 매우 중요시했으며, 이름이 그 사람의 인생을 결정짓고 좌우할 수 있다는 점에서 독특한 성명철학이 발달하기도 했 다. 작명가라는 직업은 그래서 무당이나 점술가 및 지관과

This is an Open Access article distributed under the terms of the Creative Commons Attribution Non-Commercial License (http://creativecommons.org/licenses/by-nc/3.0) which permits unrestricted non-commercial use, distribution, and reproduction in any medium, provided the original work is properly cited.
더불어 가장 오랜 역사를 지닌 직업이 되었다. 姓과 名은 그 사람의 개인적 정체성뿐 아니라 가문의 정통성을 이어받는 것이기에 특히 과거 양반계급에서는 목숨보다 더 중요하게 인식했던 것이다. 따라서 신분의 차이는 그 이름만 보고도 손 쉽게 식별이 가능할 정도였다.

우리사회가 개화의 물결을 타면서 가장 큰 변화를 보인 것은 특히 여성들의 작명 태도라 할 수 있다. 과거에는 여성 들에게 성만 주어지고 이름은 크게 신경 쓰지 않았지만 개화 이후에는 여성들에게도 공식적인 이름이 주어지게 되었기 때문이다. 이름이 부여되었다는 것은 여성들의 개인적 자존 심뿐 아니라 정체성 및 사회적 역할에도 큰 변화를 가져온 것 이 사실이다. 이처럼 성명은 개인의 인격 발달에도 보이지 않 는 영향을 끼칠 수 있다는 점에서, 그리고 자신의 일부나 마 찬가지인 이름에 대해 신경증적으로 반응한 결과 개명이라 는 극단적인 행위에까지 이르는 경우들도 많다는 점에서, 본 
저자는 작명과 개명에 관여하는 심리적 동기와 그 배경에 대한 분석적 차원의 논의를 시도해 보고자 한다.

\section{본 론}

\section{작명 심리}

한자문화권의 동양인들은 아이의 이름을 지을 때에는 그 아이에 대한 부모의 소망을 담아 작명하는 것이 상례였다. 따라서 이름 하나하나의 글자에 담긴 의미를 심사숙고하여 결정하는 것이다. 문자적 의미뿐 아니라 역술적인 운수에 맞 추어 정하기도 한다. 이름이 인간의 운명을 좌우한다는 믿음 은 특히 유교적 전통사회에서 그 뿌리가 매우 깊은 것이 사 실이다. 물론 길흥화복을 따져 무병장수와 부귀영화를 추구 하는 일은 인간이 지닌 소박한 기대로 간주할 수 있겠지만, 패가망신에 대한 지나친 두려움이나 출세일변도의 무분별 한 욕망이 도를 넘게 되면 실질적인 인성의 발달이나 교육적 측면의 가치보다 개인의 성명이나 가문의 전통 등과 같은 외 형적인 가치에 더욱 중점을 두게 되는 폐단이 생길 수도 있 다. 우리사회도 이러한 상호 모순적인 측면들을 모두 내포하 고 있기 때문에 이름에 얽힌 갈등의 소지가 매우 높다고 할 수 있다.

그러나 이에 반해서 서구인들의 이름은 단순한 호칭에 불 과할 뿐, 적어도 문자적 의미가 없다는 점에서 동양과 다르 다. 서구인들의 작명은 주로 성서의 주인공들, 성자들, 조상 들, 역사적 인물들, 또는 유명 인사들의 이름을 본떠 짓는 것 이 상례라 할 수 있다. 또한 그들이 태어난 달의 기독교적 상 징 인물에 준해서 세례명이 따로 주어지기 때문에 종교적 영향을 무시할 수 없다. 그런 점에서 동양인들은 작명에 관 한한 종교적 구속력에서 비교적 자유롭다 할 수 있다. 또한 족보를 중요시해서 항렬을 가리는 관습 때문에 이름 선택에 있어서 부분적인 제한을 받기는 하지만 좋은 글자의 의미를 선택하는 데에는 큰 어려움이 없다고 하겠다.

서구인이 선호하는 이름에는 나라별 특성에 따라 다소 차 이가 있으나 발음은 서로 비슷하다. 그럼에도 불구하고 그 발 음상의 특성을 보면 그 사람의 출신 배경을 알 수 있다는 점 에서 오히려 사회적 불이익을 당하는 수도 있다. 그러나 서구 사회의 부모들도 후손들의 이름을 지을 때에는 매우 신중하 게 판단하여 작명하기 마련이다. 특히 성서적 인물을 본 따 서 작명하는 경우에는 그 인물의 행적과 성격적 특성을 고려 하여 짓는 수가 많다.

서구사회에도 우리나라의 철수와 영희라는 이름처럼 보편 적으로 흔히 사용되는 이름들이 존재하는데, 가장 대표적인 예로 영어권에서는 잭, 로버트, 헨리, 리처드, 월터, 마이클,
빌, 조지, 찰스, 에드워드, 하워드, 앤드류, 윌리엄, 오스카, 아서, 제임스, 앨리스, 엘리자베스, 제인, 마가렛, 캐롤라인, 헬렌 등이 있으며, 불어권에서는 프랑수와, 장, 앙리, 조르주, 에밀, 미셸, 앙투안느, 자크, 도미니크, 샤를르, 앙드레, 피에 르, 르네, 줄리앙, 루시앙, 알퐁스, 마르셀, 잔느, 레옹, 알랭 등 이 선호된다. 라틴식 이름에는 안토니오, 조르다노, 마리오, 산쵸, 가르시아, 알베르토, 주세페, 프란체스카, 줄리에타, 소 피아 등이 있고, 독일식 이름으로는 볼프강, 빌헬름, 하인리 히, 아돌프, 리하르트, 루돌프, 카를, 프랑크, 오토, 마르틴, 헤르만, 테오도르, 에른스트, 에리히, 한스, 구스타프 등이 있 으며, 슬라브식 이름에는 이반, 이고르, 막심, 세르게이, 사 샤, 니나, 나타샤, 블라디미르, 미하일, 유리 등이 있다.

그러나 서구사회에서 공통으로 선호되는 유대식 이름도 존재한다. 아담, 이브, 아브라함, 다비드, 사울, 토마, 피터, 필 립, 사무엘, 존, 이삭, 야콥, 루크, 다니엘, 폴, 에마누엘, 시몬, 요셉, 사라, 마리아, 한나, 안나, 미리암 등이다. 이러한 전통 은 성서의 영향 때문이다. 특히 여성의 이름은 유대식 이름 에 따라 주어지는 경우가 흔하다. 마리아, 안나가 그 대표적 인 사례에 속한다. 우리사회에서는 언제부터인가 집에서 기 르는 개들에게 서구식 이름을 붙여주는 경향이 생겼는데 이 는 반서구적인 배타의식의 발로로 여겨지는 동시에, 우리 자 신의 상대적인 열등감을 해소하는 전치 및 투사 기제의 일 환으로 볼 수 있다.

이처럼 서구인들의 이름에는 그 어떤 의미가 달리 존재하 지 않기 때문에 그들은 과거에 그 이름의 소유자였던 인물 의 특성이나 개인적 관계 여부에 따라 이름을 붙여주었으며, 그 결과 동일한 성명도 흔해서 이름 뒤에 2세, 3세 등의 별칭 을 따로 두어 구분하기도 한다. 따라서 서구인들은 자신의 이름에 대해 동양인만큼 강한 집착을 보이지는 않았다. 그러 나 오늘날에 이르러서는 서구인들도 작명에 있어서 과거와 는 달리 개인적인 의미를 찾는 창의적인 노력을 기울이는 변 화의 추세를 보이고 있는 중이다(Kaplan과 Bernays 1999).

동양인들은 자신에게 주어진 이름 외에도 성장한 이후에 는 스스로가 따로 자와 아호를 붙임으로써 이름보다 더욱 자 주 사용하기도 했는데, 특히 양반사회에서는 일종의 멋으로 통했다. 그러나 일반 천민계급에서는 이름을 중요시하지 않 았으며, 노비는 성도 허용되지 않았다. 또한 여성들에게는 성 만 주어지고 이름은 기록에 남기지도 않았던 전통 역시 오래 되었다. 여성들에게도 공식적인 이름이 의무적으로 주어지게 된 것은 개화 이후의 일이었다. 그러한 변화는 여성들의 자 의식을 일깨우고 사회적 활동의 폭을 넓혀주었을 뿐 아니라 인격의 발달 및 정체성에도 큰 영향을 주었음이 분명하다.

그런 점에서 개화의 발단이 되었던 대한제국 말기의 단발 
령과 일제에 의해 강요된 창씨개명은 한국인의 정체성에 큰 위기와 혼란을 야기한 대표적인 사건이었다. 상투를 자르고 단발을 하라는 고종황제의 영에 강한 반발을 보인 사람들은 오랜 관습과 전통을 수호하려는 의지의 표현이기도 했지만 아버지의 권위에 대한 잠재적인 거세불안이 표면화된 것일 수도 있다. 단발령에 불복하여 자결한 사람들까지 있을 만큼 그 저항은 실로 만만치가 않았다. 그러나 창씨개명에 대한 조선총독부의 강요에 끝까지 불복한 사람들은 전 조선인의 20\%에 지나지 않았다(Jeong 1994). 물론 마지못해 창씨개명 에 응한 사람들 중에는 엉터리로 짓거나 장난기로 개명함으 로써 소극적인 저항을 보인 사람들도 적지 않았다. 자신의 필명을 이상으로 지은 김해경도 그와 유사한 심리에 근거한 것으로 보인다.

서구인이나 일본인과 달리 한국인 여성은 혼인 후에도 자 신의 성을 유지한다는 점을 자랑삼아 내세우는 사람들이 있 다. 그만큼 우리사회는 여성을 존중한다는 점을 강조하고 싶 은 동기에서 나온 주장이겠지만, 과거의 실상은 그렇지도 못 했다. 성만 유지했지 이름은 기록에 남기지도 않았기 때문이 다. 우리의 고소설 〈박씨전〉의 제목처럼 이름은 사용되지 않았으며 호적이나 묘비에도 박씨 부인 등으로만 명기되었 을 뿐이다. 따라서 그것은 여성을 존중해서가 아니라 혼인을 한 후에라도 문중의 일원임을 분명히 해두기 위함이었다.

과거에는 여성 한 개인의 존재는 중요하지 않았으며, 가문 이 더욱 중요했다. 사도세자의 부인이었던 혜경궁 홍씨도 마 찬가지다. 왕족의 일원이면서도 그녀가 속한 홍씨 가문이 더 욱 우선시된 것이다. 따라서 그녀의 이름은 중요치 않았으며 그러한 시대적 요구에 부응하여 그녀 또한 세자인 지아비의 죽음보다 자신의 문중인 홍씨 가문의 보존을 위해 더욱 고 군분투했던 것이 사실이다(Lee 2004). 동기야 어찌 됐건 남 편의 성을 따라가는 서구 및 일본의 여성보다는 자신의 고유 한 성씨를 보존하는 한국 및 중국의 여성들이 그들의 독자 성을 보장받는다는 점에서는 한결 떳떳한 위치에 있음은 주 지의 사실이다.

오늘날에 이르러 여아의 이름을 짓는 데 있어서 그 의미보 다는 발음상으로만 예쁘게 지어주는 것 또한 그리 바람직한 현상은 아닐 듯싶다. 이는 물론 서구화의 영향 때문이겠지만 남아의 이름만은 아직도 전통을 따른다는 점에서 또 다른 차원의 남녀 차별은 아닌지 따져 볼 일이다. 더 나아가 신사 고 및 페미니즘의 물결로 인해 부계의 성뿐 아니라 모계 성 을 덧붙여 개명하는 경우도 늘어나고 있는데 이 또한 합당 한 명분에도 불구하고 논란의 여지는 충분히 있다고 여겨진 다. 아무리 개방적인 서구사회라 할지라도 그러한 시도는 보 이지 않기 때문이다. 전통을 파괴하는 것만이 능사는 아니
다. 전통을 존중하되 그러한 형식을 통해서가 아니라 내용적 으로 더욱 존중되는 일이 중요하기 때문이다. 형식이 내용을 좌우한다는 신념은 허례허식으로 만연되었던 이조 5 백 년의 유교적 관습과 병폐를 그대로 답습하는 것일 수도 있기 때 문에 더욱 그러하다.

\section{필명과 예명}

역사적으로 작가들이 필명을 사용한 예는 무수히 많다. 필 명에는 자신의 이름을 변형시키거나 약자로 표기하는 수도 있고, 전혀 다른 성명으로 개조하는 수도 있다. 또한 한 사람 이 여러 개의 필명을 사용하거나 다수인이 하나의 필명을 사 용하는 등 그 용례는 실로 천차만별이라 하겠다. 자신의 본 명을 그대로 사용하는 수도 많다. 필명을 사용한 작가들로는 영국의 찰스 램, 찰스 디킨즈, 조지 엘리어트, 루이스 캐롤, C.S. 루이스, 조셉 콘라드, 조지 오웰, 아가사 크리스티 등을 비롯하여, 미국의 워싱턴 어빙, 오 헨리, 마크 트웨인, 힐다 둘리틀, 어윈 쇼오, 나보코프, 스티픈 킹, 아이작 아시모프, 닥터 쉬스 등이 있다(Carty 2000). 이외에도 프랑스의 볼테르, 몰리에르, 스탕달, 조르쥬 상드, 아나톨 프랑스, 네르발, 폴 엘뤼아르, 사강, 아폴리네르, 셀리느, 이오네스코, 로맹 가리, 이태리의 모라비아, 독일의 노발리스, 북구의 입센, 라틴 아 메리카의 네루다, 미스트랄, 중국의 노신, 일본의 바쇼, 나쓰 메 소오세키, 미지마 유키오, 다자이 오사무, 한국의 김소월, 이상 등을 그 예로 들 수 있다.

필명을 사용하는 동기는 매우 다양하다. 그러나 작가 자신 의 정체를 드러내지 않으면서 사적인 생활을 보호한다는 차 원에서 필명을 사용하는 경우가 대부분일 것이다. 또는 사회 적으로 비난의 소지가 많은 작품 내용일 경우에도 필명을 사용하기 쉽다. 대표적인 사례가 일종의 도색소설인 〈 $\mathrm{O}$ 양의 이야기〉라 하겠다. 이 소설을 쓴 작가는 폴린 레아쥬로 그녀 의 본명은 안느 데클로이며, 40 년 이상 자신의 정체를 숨겨 오다가 죽기 직전에 가서야 비로소 자신이 쓴 작품이었음을 고백하였는데 그녀는 1998년에 91세의 나이로 사망했다. 여 성의 사회적 활동을 탐탁지 않게 여겼던 시절에는 주로 여 성작가들이 남성의 이름으로 필명을 사용한 경우도 있는데 영국의 조지 엘리어트와 브론테 자매, 프랑스의 조르쥬 상드 등이 그 대표적인 사례가 되겠다.

자신의 신분을 감추기 위해 가장 많은 필명을 사용한 작 가로는 단연 볼테르를 꼽을 수 있겠다. 볼테르의 본명은 프 랑수아 마리 아루에였지만 그는 당시 루이 14세의 섭정 오를 레앙공의 근친상간을 풍자한 시를 썼다는 이유로 1 년간 바 스티유 감옥에서 수감생활을 하고 풀려난 이후부터 볼테르 라는 필명을 사용하기 시작하면서 그 후로 무려 160여 가지 
의 가명을 이용하게 되었다(Joo 1998). 그는 옥중에서도 비 극 〈오이디푸스〉를 썼을 만큼 근친상간 주제에 강한 집착을 보였는데, 프로이트가 오이디푸스 갈등 개념을 소개하기 횔 씬 이전인 1717년에 완성한 작품이었다.

이와는 달리 자신의 출신 성분이나 국적을 감추기 위해 필 명을 사용하기도 하는데, 특히 이름을 통해 손쉽게 그 배경 을 추정할 수 있는 경우에 그러하다. 예를 들면, 블라디미르 코스트로비츠키라는 이름은 누가 보더라도 슬라브인임을 의심케 하지만 이는 로마에서 태어난 귀족출신의 프랑스 시 인 아폴리네르의 본명이다. 그는 자신이 폴란드인으로 비쳐 지는 것을 원하지 않았던 모양이다. 이와 비슷한 동기에서 로맹 가리는 자신의 본명인 로만 카체프를 합법적으로 개명 했다. 그는 로맹 가리의 필명으로 성공한 후에도 또 다른 필 명 에밀 아자르를 사용하여 공쿠르 문학상을 두 번이나 수상 하는 진기한 기록을 남겼다.

유대계 러시아 출신인 아이작 아시모프 역시 폴 프렌치 또는 닥터 $\mathrm{A}$ 라는 필명을 사용했다. 폴란드 출신의 코르제니 오프스키는 영국으로 귀화하면서 조셉 콘라드로 활동했다. 유대인 작가들의 정체성 혼란에 대해서는 이미 저자가 지적 한 바 있지만(Lee 2005b), 그럼에도 불구하고 반유대 감정이 상대적으로 덜한 신대륙에서는 오히려 필명을 사용하는 경 우가 적다고 볼 수 있다. 그것은 신분상의 안전이 보장된 땅 이라는 안도감이 작용했을 수도 있지만 무엇보다 표현의 자 유가 보장되었다는 점이 작용했을 것이다.

일본의 유명한 하이쿠 시인 바쇼(芭蕉)는 본명이 무네후사 (宗房)로 그가 총애하던 제자 한 사람이 선물한 바나나를 좋 아하면서부터 일본산 바나나 나무를 뜻하는 바쇼라는 필명 을 쓰기 시작했다. 그 이전에는 무려 15 가지에 달하는 필명을 사용했다. Freud(1901)는 펜이 남근의 상징으로 흔히 이용된 다고 하였다. 따라서 펜 네임은 상징적인 남근의 이름이 된다 고 볼 수도 있다. 그런 점에서 바쇼가 자신의 수많은 필명 가 운데 하필이면 남근의 상징인 바나나를 최종적으로 선택한 것이 매우 의미심장한 결정이었다고 주장한다면 그에 대한 중대 모독이 될 것인가.

한국의 이상도 본명은 김해경이지만 그의 생존 당시 한국 을 강점했던 일본인들이 조선인을 부를 때, 김상, 이상 등으 로 호칭하던 습성에 따라 필명을 멋대로 정한 것이다. 그러 나 자신의 본명에 따라 김상으로 하지 않고, 다른 성인 이상 으로 한 것은 아들을 끝까지 책임지지 않았던 아버지에 대 한 반발심 때문이었는지도 모른다. 마크 트웨인은 자신이 젊 은 시절에 미시시피강을 운행하는 증기선에서 일할 때, 수로 안내인이 강물의 깊이를 재며 외치던 말에서 힌트를 얻어 필명으로 사용했다. 이처럼 필명은 매우 다양한 동기에서 선
정되기 마련이지만, 자세히 알고 보면 그 작가의 개인적 갈 등에서 비롯된 경우도 상당수 발견할 수 있다.

연예인들이 주로 사용하는 예명은 그 어떤 의미를 두기 보 다는 대중들의 관심과 인기를 얻고 유지하기 위한 목적에서 붙여지는 것이 상례다. 그것은 상호를 정하는 일과 동일하게 자신의 상품성을 높이기 위한 전략에서 비롯된 것이지만 개 인적인 사생활을 보호하기 위한 장치일 수도 있다. 더욱이 미국과 같이 다인종국가인 경우는 특히 그러한 경향이 농후 하다. 그 대표적인 실례가 할리우드 배우들의 예명에서 찾아 볼 수 있다. 다양한 이민자들의 조상을 지닌 그들은 가능하 다면 인구의 절대 다수를 차지하는 앵글로-색슨 계열의 이 름을 예명으로 삼는 수가 많다.

특히 할리우드를 초창기부터 거의 독점하다시피 해왔던 유대계 영화인들이 그러한 전통을 세우는 데 앞장서 왔는데, 이들은 자신들의 출신 성분을 드러내지 않는 가장 유용한 수 단으로 예명을 십분 활용한 셈이다. 단적인 예로 커크 더글 라스는 본명이 이수르 다니엘로비치로 폴란드계 유대인이 며, 토니 커티스 역시 본명이 버나드 슈바르츠로 유대계 배우 다. 본명은 라르슈카 미샤 스키크네인 로렌스 하베이는 리투 아니아 태생의 유대인으로 남아연방에서 성장한 후 영국에 서 활동한 배우다(Room 1998). 어디 그뿐인가. 명배우 폴 무 니는 프레드리히 바이젠프로인트가 본명이고, 에드워드 $\mathrm{G}$. 로빈슨은 에마누엘 골덴베르크가 본명이다. 또한 명감독 윌 리엄 와일러의 본명은 빌헬름 바일러이며, 우디 앨런 감독의 본명은 앨런 스튜어트 코닉스버그다.

예명은 영화인들뿐 아니라 거의 모든 가수들도 사용한다. 예를 들어 미국의 가수 보비 다린의 본명은 월든 로버트 카 소토였다. 이태리 이민자 출신의 가난한 노동자 계급의 집안 에서 태어난 그는 어려서부터 선천성 심장질환으로 오래 살 기 힘들겠다는 진단을 받았으나 성장한 이후 가수로 데뷔하 면서 어릴 때 애칭인 보비라는 이름과 더불어 자신의 성을 다 린으로 바꾸었다. 다린이라는 성을 선택한 것은 중국식당 상 호인 만다린 덕을 실수로 오기한 다린 덕에서 힌트를 얻었 다고 한다.

이처럼 예명을 사용한 가수들은 마리아 칼라스, 마리오 란 자, 알 졸슨, 미나, 에디트 삐아프, 코니 프란시스, 바비 빈튼, 브렌다 리, 페기 리, 패티 페이지, 밥 딜란, 맷 먼로, 토니 베 네트, 도나 서머, 클리프 리차드, 처비 체커, 존 덴버, 잉글버 트 험퍼딩크, 스티비 원더, 조니 미첼, 룰루, 셰어, 캐롤 킹, 조 지 마이클, 링고 스타, 시나 이스턴, 크리스탈 게일, 티나 터너, 보니 타일러, 데이빗 보위, 앨리스 쿠퍼, 마릴린 맨슨, 프린 스, 보이 조지, 마돈나, 엔야 등에 이르기까지 무수히 많다.

그러나 가수들의 경우는 자신들의 상품성을 더욱 노골적 
으로 드러낸다는 점에서 영화인들의 예명에 비해 매우 의도 적인 명칭을 구사하는 수가 많다. 더군다나 서로 간에 경쟁 이 치열하기 때문에 대중들의 눈에 더욱 잘 띄게 하기 위해 서 자극적인 예명을 동원하기 쉽다. 따라서 매우 저급하고 부 도덕한 명칭을 의도적으로 사용하는 수도 있다. 마릴린 맨슨 의 경우가 그렇다. 마릴린 먼로와 찰스 맨슨의 이름을 조합 시킨 이 예명은 섹스의 심볼과 폭력 살인의 심볼을 합성시켰 다는 점에서 그 의도를 엿볼 수 있기 때문이다. 사탄 록의 대 명사 앨리스 쿠퍼의 경우도 본명은 빈센트 데이먼 퍼니어다.

건즈 앤 로즈는 총과 장미를 뜻하는 예명으로 각기 남녀의 성기를 상기시킴으로써 청소년들을 의도적으로 자극한다. 주 다스 프리이스트는 유다와 승려를 합성시킨 예명으로 반그 리스도적인 전도사임을 자처한다. 실제로 이들은 무대 의상 이나 분장도 기괴한 모습의 차림으로 나타나 악마적인 분위 기를 고의적으로 연출함으로써 보수적인 기독교적 사회 분 위기에 염증을 느끼는 젊은 세대들로부터 강한 호소력을 얻 고 있다. 그러나 이처럼 강력한 영향력을 행사하는 반지성 적, 반기독교적 메시지의 전파는 비단 미국사회에 머무는 현 상이 아니라는 점에서 문제의 심각성이 있는 것이다. 어떻게 보면 광우병의 침입보다 이와 같은 악마성의 메시지 침투가 더욱 염려되는 부분이다.

물론 오늘날과 같은 글로벌시대를 맞이하여 어느 사회나 청소년기의 반항은 있을 수 있는 보편적인 현상으로 받아들 이고는 있지만, 설사 그렇다 치더라도 이처럼 근친상간 및 자 살 권장, 폭력 찬양, 마약 권유, 집단성교 등 노골적인 반사 회적 메시지를 전파한다는 점에서는 정체성이 채 확립되지 못한 시기의 우리 청소년들에게 악영향을 끼칠 수 있다는 점에 서 사회적 관심이 더욱 요구되는 부분이기도 하다(Lee 2005a).

실제로 오늘날의 청소년들에게 이들이 전하는 메시지가 부모의 훈계를 능가할 수밖에 없는 이유로 가족 간 대화 시 간의 부족과 부모의 무관심, 그리고 과도한 학업 위주의 강 제적인 교육체제 등을 들 수 있다. 또한 날로 번창하는 인터 넷, MP3 등 대중매체의 보급으로 이들 메시지에 접근이 매 우 용이하다는 점, 그리고 부모와 접촉하는 시간이 매우 제 한적인 데 반해 항상 귀에 꽂고 다니며 이러한 음악에 접할 수 있는 시간이 상대적으로 무제한적이라는 점 등이 그러한 위험성을 더욱 배가시키고 있는 것이다.

\section{별명의 심리}

별명은 부정적인 측면과 긍정적인 측면 두 가지가 존재한 다. 부정적인 측면의 별명은 상대를 놀리기 위한 목적으로 붙여진다. 누구나 학창시절에는 친구 또는 스승에게 붙여진 별명에 익숙할 것이다. 불량써클에 붙여진 악명 높은 별명
또한 누구나 한번쯤은 들어봤음 직하다. 대개의 경우 그런 별명은 그 해당 인물이나 집단의 특성을 압축적으로 나타낸 말이기 쉽다. 특히 별명이 주어진 인물은 집단 따돌림이나 놀림감의 대상이 되기 쉬운데 상대의 성격적 미숙함이나 신 체적 결함을 지닌 경우가 많다.

Freud(1905)는 이름과 관련된 농담의 많은 사례들을 소개 한 바 있지만, 일반적으로는 발음이 유사하면서 부정적인 감 정을 유발시키는 이름인 경우, 예를 들면 임신중, 홍성교, 김 일성, 박은희, 김성기, 변기충 등에서 보듯이 놀림의 대상이 되기 쉬운 이름은 무수히 많다. 그러나 문제는 단순한 언어 적 희롱에 그치는 것이 아니라 날이 갈수록 폭력화 되어간 다는 점이며 그 방식도 매우 가학적이고도 잔혹해져 간다는 사실이다. 유명인의 이름을 장난 삼아 희화화시키는 수도 있 다. 프랑스 작가 에밀 졸라의 이름을 에미를 조른다는 의미 로 사용하는 경우가 그렇다.

별명은 암흑가의 범죄 집단에서도 흔히 사용된다. 조직 및 조직원의 이름을 별명으로 붙이는 것은 자신들의 정체를 은 폐시키고 법망을 피하기 위한 목적으로 사용하는 것이다. 군 대사회에서는 자신들이 애용하는 전투기나 군함 및 전차 등 에 별명을 붙여주는 경우도 있다. 병사들에게 인기 있는 소 위 핀 업 걸에게도 개인적인 별명을 붙여 부르기도 한다. 심 지어는 부모가 자식들을 별명으로 부르는 수도 있다. 꾀돌 이, 미련 곰탱이, 밥순이, 꺽쇠, 미꾸라지, 황소 등으로 호칭하 는 경우는 자식들의 개인적인 버릇이나 특성에 따라 붙여지 는 것이다. 마크 트웨인의 소설〈톰 소여의 모험〉에서 톰은 어른들이 기분 좋을 때 부르는 이름이지만 갑자기 토마스라 고 하는 경우는 뭔가 일이 생겼을 때 불리는 호칭으로 묘사 되고 있다. 이처럼 별명은 부정적이든 긍정적이든 어느 사회 에서나 매우 보편적으로 상용되는 현상이다.

별명은 사회적 지도자에게도 붙여진다. 미국에서는 대통령 에 대한 애칭이나 약칭 차원에서 별명이 자주 사용된다. 아 이젠하워 대통령을 아이크라고 부르거나 루즈벨트 대통령 을 테디라고 부른 것이 그 대표적인 사례다. 우리나라에서도 김대중 전 대통령을 $\mathrm{DJ}$ 로, 김종필씨를 $\mathrm{JP}$ 로, 김영삼 전 대통 령을 YS로, 이명박 전 대통령을 $\mathrm{MB}$ 등의 약칭으로 부른 것 은 잘 알려진 사실이다. 역사적인 인물로 유고의 티토 대통 령은 제2차 세계대전시 빨치산 활동을 할 때부터 티토라는 별명으로 유명했다. 그의 본명은 요집 브로즈였다. 그러한 별 명은 체 게바라, 김일성, 스탈린, 레닌, 트로츠키, 지노비에 프, 카메네프, 호지명, 폴 포트 등 혁명가들이 주로 사용했 다. 전설적인 혁명가 체 게바라의 본명은 에르네스토 라파엘 게바라 드 라 세르나이며 발음하기에 너무 번거롭기 때문에 그의 이름 가운데 하나로 줄인 것이다. 
그러나 신변의 안전을 도모하기 위한 목적으로 가명 및 별명을 사용한 경우는 주로 혁명가 출신들에서 흔히 볼 수 있다. 레닌의 본명은 블라디미르 일리치 울리아노프였으며, 스탈린의 본명은 이오지프 비싸리노비치 주가시빌리, 트로 츠키의 본명은 레브 다비도비치 브론쉬타인, 카메네프의 본 명은 레브 보리소비치 로젠펠트, 몰로토프의 본명은 비야체 슬라프 미하일로비치 스크리아빈이었다. 이외에도 김일성 의 본명은 김성주였으며, 킬링 필드로 악명을 떨쳤던 폴 포트 의 본명은 살로스 사르, 전 서독 수상 빌리 브란트의 본명은 헤르베르트 에른스트 칼 프라암이었다. 이들 모두는 정치적 활동에 뛰어들면서 이름을 바꾼 것으로 특히 자신의 정체를 은닉시키기 위한 목적에서 그랬을 것이다. 이처럼 신변의 안 전을 위해서도 그랬겠지만 이러한 별명은 일반 대중들에게 신비감을 더욱 조장하기 때문에 의도적인 것일 수도 있다.

그러나 오늘날에 와서는 특히 운동선수들에서 이러한 별 명을 흔히 볼 수 있다. 축구황제 펠레를 위시하여 조 루이스, 로키 마르시아노, 무하마드 알리, 베이브 루스, 압둘 자바 등 은 잘 알려진 별명이다. 이들처럼 대중들의 사랑을 한 몸에 받으며 매일처럼 입에 오르내리는 경우, 본명이 너무 길거나 발음이 어렵기 때문에 호칭하기에 간편한 별명을 지어 부르 는 수가 많다. 그러나 〈다빈치 코드〉라는 영화 제목에서 볼 수 있듯이 레오나르도 다 빈치를 줄여서 그냥 다빈치로 부르는 것은 분명 잘못된 호칭이다. 빈치는 플로렌스 지방의 한 지 명 이름일 뿐이다. 사생아로 태어난 그의 본명은 레오나르도 디 세르 피에로이며, 중세 서구에서는 태어난 지명을 이름 뒤에 붙여 쓰는 것이 관습처럼 되어 있었기 때문에 정확히 번역하자면 빈치의 레오나르도다.

예수회의 창시자 로욜라도 이와 유사한 경우라 할 수 있다. 보통 로욜라의 이그나티우스로 불린다. 그의 본명은 이니고 오나즈 로페즈 데 로욜라이며, 여기서도 로욜라는 스페인 북 부 바스크지방의 한 지명을 가리키는 것으로 그의 출생지이 기도 하다. 굳이 그런 식으로 부른다면 프란체스카 다 리미니 의 경우도 다 리미니로 불러야 되겠지만 이는 분명 실수다. 아시지의 성자 프란체스코의 본명도 원래는 피에트로 디 베 르나도네였지만 교회의 공식 호칭인 성 프란체스코로 불리 게 된 것이다. 알바니아 태생의 수녀 마더 테레사도 아그네 스 곤자 보자지우의 본명을 지녔지만 교회의 공식 호칭인 마더 테레사로 정착되었다. 이와는 달리 갈릴레오 갈릴레이 의 경우는 성과 이름의 발음이 비슷하여 잘못 호칭되는 경 우가 많다. 이처럼 별명의 경우도 본인의 의사와는 관계없이 사용자들의 실수나 오해에서 비롯되는 수도 많다. 그러나 일 단 관습으로 굳어지게 되면 새로 정정하기가 쉽지 않다.

\section{가명과 익명}

가명의 사용은 대개의 경우 부정적 인상을 주기 쉽다. 특히 범죄의 목적으로 가명을 사용하는 수가 많기 때문이다. 그것 은 익명의 사용과 비슷한 동기에서 부정적일 수 있다. 자신 의 신분을 감춘다는 점에서는 차이가 없으나 헌금이나 자선 을 베푸는 사람의 경우에도 가명이나 익명을 사용하는 수가 있다. 진 웹스터의 소설 〈키다리 아저씨〉에서 한 고아소녀를 남몰래 돕는 익명의 후원자 경우가 이에 속한다. 그러나 Yi(1988)의 소설 〈익명의 섬〉에서는 익명성의 문제가 그리 간단한 문제가 아님을 실토하고 있다. 왜냐하면 익명성이란 두 개의 상반된 얼굴을 지니고 있기 때문이다. 마치 그것은 양날을 가진 면도날과도 같은 효과를 안고 있기 때문이다. 익명성이 보장된 도시공간의 도덕적 타락상과 익명성이 차 단된 폐쇄적 공간 내에서 벌어지는 부도덕한 욕망의 세계가 대비되는 우리의 현실이 매우 이율배반적이라는 느낌을 준 다. 그것은 곧 열린사회와 닫힌사회의 특성으로 모든 문제를 단순화시키기 어려운 것과 같다고 할 수 있다. 어차피 인간은 환경의 영향을 받고 살지만, 그가 처한 환경이 모든 것을 결 정짓는 것은 아니기 때문이다.

범죄의 목적이나 상대를 비방하기 위한 수단으로 가명 및 익명을 사용하는 경우에는 그 법적 책임이 따른다는 점에서 사회적 감시체계의 확립이 절실히 요구된다. 특히 오늘날에 이르러 인터넷을 통한 익명성의 횡포는 실로 심각한 사회적 문제가 되고 있다. 그것은 전통적으로 칭찬에 인색한 우리사 회의 약점을 반증하는 현상이기도 하지만 억압된 적개심 및 공격성의 적절한 출구가 달리 존재하지 않음을 반증하는 것 이기도 하다. 익명에 의한 악성 댓글의 가장 큰 피해자는 인 기 연예인들이라고 할 수 있다. 익명성이 보장되는 인터넷 매 체의 가장 큰 특성은 퇴행을 조장한다는 점이다.

그럼에도 불구하고 Turkle(1997)은 인터넷의 등장이야말 로 새로운 글로벌시대에 가장 적합한 형태의 정체성 출현을 알리는 것으로 네티즌사회의 특성을 매우 긍정적인 시각에 서 평가한다. 즉 인터넷의 출현으로 성차의 극복이 이루어지 면서 평등성이 보장되고 공감대의 형성이 보편화되는 등의 변화가 가능하게 되었다는 것이다. 그러나 그녀의 낙관적인 기대는 너무 현실을 앞서간 느낌이 든다. 인터넷의 역기능적 측면에 대한 충분한 관찰과 경험을 토대로 하지 않고 단순 히 페미니즘적 열정에 입각한 나머지 너무 성급한 판단을 내린 것이 아닌가 하는 느낌을 지울 수 없다. 그것은 인터넷 자체의 특성뿐 아니라 매체를 이용하는 네티즌들의 심리적 상태 또한 중요한 요인이기 때문이다.

물론 모든 퇴행이 잘못된 것은 아니지만, 수많은 청소년들 이 심각한 인터넷 중독에 빠져 헤어나지 못하거나 악랄한 
익명성의 횡포 문제는 비단 우리사회에만 적용되는 병폐는 아닐 것이다. 결국 인간 심성의 올바른 형성이 우선되는 것 이며, 문명의 이기는 그러한 전제하에 가능할 수 있는 문제 로, 그렇지 못할 경우에는 순식간에 문명의 흥기로 돌변할 수 있는 것이기 때문에 그리 간단한 문제는 아니라고 본다.

\section{개명의 동기}

앞서 언급한대로 지배자의 강압에 의해 정치적으로 강요 된 창씨개명은 그 집단의 정체성을 위협하는 잔인한 범죄에 속한다. 그것은 강요된 종교적 개종에 버금가는 정신적 가학 행위라 할 수 있다. 이처럼 강압에 의해 일단 개명이나 개종 이 이루어지게 되면 그 집단은 깊은 좌절감에 빠져 다시 재 기하기 어려운 지경에 이르기도 한다. 그러나 개인적인 이유 에서 자신의 이름을 공식적으로 바꾼다는 것은 부모가 지어 준 이름 자체에 대한 불만뿐 아니라 부모의 존재 및 그 권위 자체에 대한 부정일 수 있다. 자신의 소중한 이름을 거부한 다는 것은 이미 그 자신이 정체성의 혼란 및 그 인격을 대표 하는 고유명사이기도 한 상징적 표상을 거부하는 것이다. 따 라서 법적인 개명은 종교적인 개종에 버금가는 삶의 중대사 가 아닐 수 없다. 그것은 부모가 믿는 종교가 명백한 사이비 종교가 아님에도 불구하고 이를 거부하고 굳이 다른 종교를 선택하는 자식들의 심리적 동기와 비슷할 수 있다.

정체성의 개념을 최초로 소개한 Erikson(1956)은 그 자신 이 청년 시절 정체성의 혼란을 몸소 겪었던 분석가로 성장 한 이후 계부의 성에 따른 자신의 본명 에릭 홈부르거를 에 릭 에릭슨으로 바꾸었다. 물론 그의 친모와 계부는 모두 유 대인이었지만 신원을 알 수 없는 그의 친부는 덴마크인으로 만 알려졌을 뿐 그가 어렸을 때 이미 가족을 버리고 사라져 버렸기 때문에 어머니가 재혼하기 전까지 그는 유대인 사생 아 취급을 받아야 했다. 그 자신의 정체성에 대한 불만과 혼 란은 비록 친부의 성은 모르지만 스칸디나비아 계통임을 암 시하는 에릭슨이라는 성을 선택하도록 이끌었다. 그러나 친 자가 아님에도 불구하고 그를 끝까지 후원했던 계부에 대한 고마움을 모르는 바가 아니었기 때문에 그는 개명한 이후에 도 계부의 성을 함께 사용함으로써 공식적으로는 에릭 홈부 르거 에릭슨이라는 이름을 사용했던 것이다. 이처럼 이름의 변동 과정에도 그 개인의 심리적 과정이 복잡하게 연관됨을 알 수 있다.

개명의 동기 면에서 본다면 프랑스의 소설가 로맹 가리만 큼 복잡한 인물도 드물 것이다. 그 역시 심각한 정체성의 혼 란을 겪었던 유대계 출신 작가다. 러시아 모스크바에서 사생 아로 태어난 그는 홀어머니 밑에서 성장했으며, 어린 시절에 어머니와 함께 러시아를 떠나 리튜아니아, 폴란드 등지로 전
전하다가 프랑스에 가까스로 정착했다. 작가의 길로 접어들 면서 아버지의 성인 카체프를 버리고 로맹 가리로 개명했으 나, 문제작을 발표하여 공쿠르상을 받는 등 작가로 성공한 후에도 수시로 다른 필명을 사용하였으며, 더 나아가 에밀 아 자르라는 필명으로 작품을 발표하여 두 번이나 공쿠르 문학 상을 수상하는 이변을 낳기도 했다. 그는 자신의 아내였던 여 배우 출신 진 세버그가 의문사한지 일 년 뒤에 총기 자살로 생을 마감하고 말았는데, 마지막 유고를 통해 로맹 가리와 에 밀 아자르가 동일 인물임을 밝힘으로써 비슷한 시기에 부인 을 목 졸라 살해한 철학자 알튀세르 사건과 더불어 전 세계 에 충격을 안겨주기도 했다.

이처럼 정체성 혼란의 문제는 개명의 가장 큰 심리적 동기 로 작용한다. 개명의 전통은 집단적으로는 2천 년간 조국을 잃고 방랑생활을 거듭했던 유대인들에서 가장 보편적으로 발견되는 현상이라 할 수 있다. 그들은 특히 서구사회에서 살 아남기 위한 자구책으로 자신들이 정착하는 문화권의 특성 에 맞추어 이름을 수시로 바꾸어야 했다. 돈만 아는 수전노 라는 유대인에 대한 편견은 그들 스스로가 붙인 이름에도 반 영된다. 골드만, 골드버그, 골드스톤, 골드스타인, 골드스미 스 등, 황금을 의미하는 골드는 수많은 유대인 성에 전매특 허처럼 사용된 것으로 정평이 나있다. 그것은 우리나라 성에 김씨가 많은 것과는 그 동기 면에서 분명히 차이가 있다. 비 록 우리나라는 예로부터 금이 풍부했던 것으로 알려졌지만 유대인과 같은 물질적 동기에서 붙여진 것은 아닌 듯하다.

어쨌든 유대인들은 물질적 성공에 대한 욕심을 애써 감추 지 않았던 것이 분명하다. 따라서 그런 전통은 오늘날에 이르 기까지 이어져 골드만-삭스 등의 유대계 재력가가 전 세계 경제를 좌지우지할 정도의 힘을 행사하고 있는 것이다. 그러 나 막강한 힘을 얻은 인물은 굳이 자신의 신분을 감출 필요 가 없기 때문에 개명에 대한 동기가 사라질 수밖에 없을 것 이다. 그것은 특히 미국과 같은 자유민주주의국가에서는 더 욱 개명의 필요성이 약화될 소지가 많지만, 외지인에 대한 배타적 분위기로 사회적 불이익이 가해지기 쉬운 지역에서 는 그만큼 개명의 가능성이 높아질 수밖에 없다. 유대인 멸시 와 박해가 특히 심했던 독일, 러시아 등지에서 현지인의 성을 모방하는 경우가 많았던 것도 그러한 사회적 분위기 때문이 었다.

정체성 문제 이외에 개명의 동기로는 개인적 이유를 들 수 있다. 부모 및 그 가문 자체에 대한 개인적인 불만이나 회의 에서 비롯된 감정적인 이유로, 또는 자신에 대한 열등감이나 자존심의 문제를 이유로 개명하는 수도 있다. 그러나 족보를 중요시하는 우리나라에서는 일제의 강요에 의한 창씨개명 이후에는 성씨까지 바꾸는 경우는 거의 없다. 물론 과거에 왕 
조가 바뀌면서 신변의 위협을 느껴 신분을 감추어야 했던 왕씨 일족이 전씨로 개명한 경우나 역모죄 등으로 패가망신 한 경우, 본의 아니게 성씨개명을 한 일은 있었을 것이다. 이 처럼 신분상의 이유뿐 아니라 발음하기가 어려워서 또는 발 음이 이상하다는 현실적인 이유로 개명하기도 한다. 신씨를 영문으로 표기할 때 Sin으로 하지 않고 Shin으로 하는 것은 그 의미가 잘못 오해받기 쉽기 때문일 것이다.

그러나 특히 희성인 경우는 성씨의 발음과 연결되는 이름 의 조합에 따라 불필요한 오해를 사는 수도 있기 때문에 작 명을 할 때부터 신중을 기하기 마련이다. 따라서 이처럼 의 미 전달에 오해의 소지가 많거나 불쾌감을 조성할 여지가 많은 경우에는 뒤늦게나마 개명을 시도할 수는 있겠지만, 우 리사회에서는 성씨까지 고치는 경우는 극히 드물다고 할 수 있다. 또한 우리사회에서는 동물의 이름을 성씨로 사용하는 경우가 거의 없는데 반해, 서구인들은 Fox, Wolf, Bear, Turtletaub, Fish, Nightingale, Spitz, Pigeon 등의 성을 자연스 럽게 사용하기도 한다. 우리나라의 경우처럼 이름 때문에 불 행이 올 수 있다는 미신적 이유로 개명하는 수도 있다. 과거 에는 하층민의 경우, 불길한 마가 끼지 않도록 한다는 의도 에서 고의적으로 이름을 개똥이, 쇠똥이 등 혐오감을 불러일 으키는 이름으로 지었던 적도 있다. 이름만 들어도 사악한 기 운이 겁을 내어 물러선다는 이유에서였다. 그러나 이유야 어 찌됐건 공식적인 개명은 우리사회에서 매우 힘든 작업임에 틀림없다. 적어도 이름에 관해서만큼은 유교적 전통의 영향 에서 아직까지 그리 자유롭지 못하다는 사실을 반증하는 것 이겠다.

\section{분석적 토론}

이름의 중요성은 그 당사자의 정체성 확립과 유지라는 측 면에서 특히 강조될 수 있다. 또한 부모와의 관계 및 그 자신 의 자식들과의 관계, 그리고 사회적 관계의 유지에도 매우 중요한 의미를 내포하기 쉽다. 자신의 이름에 대한 애정 및 자긍심은 모든 대인관계에도 긍정적인 효과를 미칠 수 있다. 자기에 대한 태도가 자신의 이름에 대한 태도에도 반영되기 쉽다. 부모에 대한 분노와 적개심으로 그들에게서 물려받은 자신의 이름에 대한 부정적인 태도로 연결되는 일은 우리 주위에서도 흔히 발견되는 현상이다.

아동기적 사고의 단계에서는 부모가 자신의 요구를 들어 주지 않을 때, 흔히들 자신의 친부모 여부를 의심하는 경우 도 많다. 일종의 가족환상에 빠져 좀 더 나은 환경의 부모를 상상하는 것이다. 이는 자신의 부모 및 가계에 대한 부정이 다. Freud(1909)는 이를 가족 로망스라고 불렀다. 소위 미뇽 망상이라고 하는 것은 이를 두고 하는 말이다. 그러나 성장
해 가면서 아동들은 적절한 화해와 타협을 모색하기 마련이 다. 그러한 시도가 여의치 못할 때, 많은 청소년들은 환상적 인 가계에 대한 꿈을 버리고 그 대신에 자신의 이상적인 우상 이나 영웅을 찾아 그에게 몰두한다. 그것은 종교적, 정치적 혁명가일 수도 있고 흔히는 연예인 또는 운동선수에 몰두하 여 그를 열광적으로 추종하기도 한다. 형제에 대한 불만은 사조직이나 종교단체 등에 가입함으로써 부분적으로 해소 하기도 한다. 보다 우호적인 새로운 형제애를 추구하고 만족 을 얻는 것이다.

Freud(1913)는 〈토템과 타부〉에서 미개인들의 경우 죽은 사람의 이름을 입에 올리는 것조차 금기시한 점에 주목하고, 그 이유는 그들 역시 이름을 한 개인이 지닌 인격의 본질 및 소유물로 간주함으로써 죽은 자의 이름과 그 인경을 동일시 하기 때문이라는 것이다. 그러나 미개인뿐 아니라 아동들의 경우에도 서로 다른 사물이 같은 이름으로 불릴 경우, 그 이 름의 유사성에도 불구하고 두 사물 사이에 아무런 의미상의 유사성이 없다는 설명을 받아들이지 않으면서, 일단 발음이 비슷하면 틀림없이 의미 있는 공통점이 존재할 것으로 믿는 다는 것이다. 그리고 이러한 특성은 문명사회의 성인들도 결 코 예외가 아니라고 하였다.

프로이트의 이러한 견해는 달리 말해서 원초적 단계에 형 성되는 마술적 사고의 흔적을 말하는 것으로 이해할 수 있 으며, 이를테면 죽을 死자와 숫자 4의 발음이 같다고 해서 4 라는 숫자를 불길한 징조로 받아들이는 우리사회의 미신적 풍조에서도 확인할 수 있는 사고의 유형이기도 하다. 따라서 건물에도 4층을 따로 표기하지 않거나 엘리베이터에도 4층 만은 영문 $\mathrm{F}$ 로 표시하는 수가 많은데 누구도 이의를 제기하지 않는 이유는 절대 다수의 공감대가 형성되어 있기 때문이다.

Murphy(1957)는 생후 1세부터 2세 사이에 그 자신의 신 체기관뿐 아니라 자신에게 주어진 이름을 자아의 일부로 받 아들이게 되면서 그 이름 자체가 주된 방어기제의 유형을 형 성하는 데 매우 중요한 역할을 맡는다고 하였다. 그리고 자 아가 발달해 감에 따라 자신의 이름에 대한 환상도 커지게 되 며, 경우에 따라서는 이름 자체에 대한 문제가 성인이 된 이 후 신경증의 핵심적인 부분을 차지하는 수도 있다고 하였다.

Oberndorf(1920)는 특정한 이름에 대한 이유 없는 거부감 이나 혐오감의 이면에는 드러나지 않은 무의식적 감정문제 가 자리 잡고 있기 때문이며, 그러한 이유 때문에 개명을 시도 하는 경우도 흔히 있음을 이미 지적한 바 있다. Sharpe(1946) 는 모든 명칭에는 좋고 나쁨의 이분법적 잣대가 무의식적으 로 적용되는 수가 많다고 하면서 여기에는 초자아의 개입이 중요한 역할을 맡는다고 하였다. 이러한 경우는 사람의 이름 에도 적용될 수 있다. 아동기 시절에 흔히 겪는 일이지만, 이 
름이 마음에 들지 않는다면서 친구가 되기를 거절하는 경우, 그 배경에는 무의식적 초자아의 개입을 생각해 볼 수 있다.

Freud(1917)는 이름과 관련된 실수를 통하여 그 무의식적 의미를 탐색하는 데 일가견이 있었는데, 특히 분석시간에서 는 이러한 이름에 대한 말실수나 누락 여부가 매우 중요한 단 서를 제공하는 수도 많다(Meyer 1923; Abrams 1982; Strean 1984). 이와 비슷한 사례들은 우리의 일상생활에서도 얼마든 지 발견할 수 있는 현상으로, 예를 들면 친구들과 대화중에 자신의 옛 스승 이름을 떠올릴 때, 기억의 실수로 그 사람의 신체적 결함을 의미하는 단어로 대체시키는 경우가 있을 수 있다. 그러한 경우 그 스승에게 몹시 혼났던 좋지 않은 과거 경험 때문에 잠재되어 있던 부정적 감정의 영향으로 기억의 왜곡이 일어난 것이다. 그것은 긍정적 감정을 지녔던 대상의 경우에도 일어날 수 있다. 과거 자신의 첫사랑이었던 인물의 이름이 얼른 기억나지 않는 경우도 현재의 배우자에 대한 죄의식 때문에 회상에 어려움을 겪을 수가 있기 때문이다.

프로이트는 신경증의 기원을 오이디푸스 갈등으로 설명 하면서 그 핵심적인 구조를 근친상간적 욕구와 거세위협에 대한 불안으로 요약하였다. 따라서 부모와 아동 간에 형성되 는 심리적 삼각관계가 그 요체인 셈이다. 그러나 라캉은 아버 지의 존재가 이러한 구도에 반드시 동참할 필요는 없다고 주 장했다. 그것은 아버지의 이름이 지니는 상징적 효과만으로 도 이미 아이에게 영향을 끼친다는 것이다(Lacan 2006). 앞 서 언급했던 로맹 가리 및 에릭슨의 경우에서 그런 사실을 확 인할 수 있다. 로맹 가리는 아버지의 이름을 부정한 사례이고, 에릭슨은 아버지의 이름을 되찾고자 시도한 경우라 할 수 있다.

이처럼 상반된 태도는 실제의 아버지와 살아본 경험이 없 는 경우에도 정체불명의 아버지에 대한 감정적 반응의 차이 에서 비롯된 것으로 이해할 수 있다. 두 인물 모두 유대인 출 신이지만 어머니에 대한 태도 면에서도 차이가 있다. 로맹 가리는 홀어머니 밑에서 성장하며 그녀의 과잉보호를 받았 지만 에릭슨은 어머니가 재혼함으로써 그녀의 존재를 의붓 아버지에게 빼앗긴 셈이다. 따라서 행위상으로는 똑같이 개 명했음에도 불구하고 그 심리적 배경은 이처럼 다른 것이다.

이들처럼 성씨까지 바꾼 것은 아니지만, 프로이트는 성장 한 이후에 그 자신의 유대적 기원을 부정하고 독일식 이름인 지그문트로 개명했다. 그의 출생시 이름은 원래 쉴로모 지기 스문트였다. 솔로몬 왕을 의미하는 쉴로모라는 이름에 마음 에 들지 않았기 때문이다(Gay 1987). 그에게 원래 주어진 이 름으로 봐서는 솔로몬의 지혜와 헝가리의 전설적인 영웅 지 기스문트의 용기를 모두 겸비했으면 하는 부모의 기대가 있 었을 것이다. 그러나 어린 프로이트가 진심으로 숭배했던 인
물은 그들이 아니라 카르타고의 영웅 한니발이었다(Freud 1925). 이에 반해 프로이트의 이론에 불만을 품고 그와 결별 했던 칼 구스타프 융은 순수 독일인의 이름을 지녔던 인물로 기회가 있을 때마다 자신이 괴테의 먼 후손임을 주장하였는 데, 이는 일종의 가족환상으로 볼 수도 있다. 그러나 근본적 으로는 열등하고 불순하기만한 유대적 기원에 물든 서구문 화의 정화를 외치면서 한 때나마 나치 이데올로기의 선구자 역할을 수행하기도 했다는 점에서 본다면, 순수 독일인의 우 수성을 스스로에게도 확인할 필요가 있었는지도 모른다(Noll 1994; Noll 1997).

이와는 달리, 이들 두 천재 사이에서 극심한 정체성의 혼 란을 겪었던 러시아 태생의 분석가 자비나 슈필라인은 융에 게 분석받는 도중에 강한 전이적 사랑에 빠지면서 융과의 사 이에서 자신이 아기를 낳으면 그 이름을 지그프리트로 짓는 다는 환상을 지니게 되었다(Carotenuto 1984; Kerr 1993). 그 이름은 자신과 같은 유대인 여성과 순수 독일인 천재인 융 사이에서 태어난 아기에게 그보다 더 적합한 이름은 없다고 판단했기 때문이다. 그러나 공교롭게도 지그프리트라는 이 름은 프로이트의 이름 지그문트와 매우 유사하다는 점에서 그녀의 무의식적 환상속에 융과 프로이트라는 두 천재 모두 를 자신의 내면적 대상으로 간직하고자 했던 것은 아닌지 모르겠다.

지금까지 고찰해 본 바와 같이 사람이 자신 및 후손들의 이 름에 집착하는 것은 다 그만한 이유가 있기 때문이다. 이름 은 자신과 타인을 구분하는 중요한 근거가 될 뿐 아니라 자신 의 독자성을 대표하는 얼굴과도 같은 것이다. 또한 특정 가 문의 일원으로서 안정적인 소속감을 제공하기도 한다. 그런 점에서 명함은 사회생활에 매우 중요한 교류 수단이 된다. 상대의 이름을 확인하는 일부터 사회적 교류가 시작되기 때 문이다. 성명을 밝히지 않는 행위는 상대에게 불신과 의혹을 증폭시키기 마련이다. 더 나아가 이름을 밝히는 행위로도 충 분히 안심을 할 수 없기 때문에 악수를 청함으로써 상호 간의 불신과 의혹을 제거하고 우의를 다지는 것이다.

이처럼 이름은 사회적 관계 형성에 결정적인 지렛대 역할 을 하는 것이기에 그 이름을 바꾼다는 일은 매우 강력한 개 인적 동기가 작용하지 않고서는 손쉽게 이루어지는 현상이 아니다. 특히 새로운 환경에 노출됨으로써 적응상의 어려움 에 놓일 때, 열등감 및 좌절감에서 비롯된 정체성의 혼란이 야기되기 쉽다. 이러한 정신적 위기 상황에서 자아의 변화가 생각처럼 용이하지 못할 경우, 마치 성형수술로 자신의 이미 지 변신을 시도하듯이 새로운 개명을 통하여 자기 변신을 도 모할 수 있다. 따라서 개명은 불가피한 위기적 상황에서 탈 피할 수 있는 매우 유용한 기회를 제공해 줄 수도 있을 것이다. 


\section{결 론}

우리에게 이름이 갖는 의미는 생각보다 매우 크다 할 수 있다. 인간이 성장하면서 성격도 변하고 외모도 변하지만 이 름만큼은 태어나서 죽을 때까지 지니고 가는 것이기 때문이 다. 그리고 자신의 이름을 드높이기 위해 다른 말로 해서 소 위 명성을 얻기 위해 모든 희생과 노력을 아끼지 않는 사람 들도 많다. 따라서 자존심을 유지하는 동시에 전 인격을 대 표하는 대명사이기도 한 자신의 고유한 이름에 대한 모독은 참을 수 없는 심리적 상처를 남기기 마련이다. 성장과정 중 에 한때 자신이 얻었던 별명을 잊어버리는 사람은 별로 없 을 것이다. 또한 가문을 대표하는 성씨에 대한 자부심 또는 열등감은 인격 형성에도 영향을 줄 수 있다.

이처럼 다양한 이유 때문에 삶의 도중에 개명을 시도하는 사람들도 있다. 그러나 그것은 신앙적 개종만큼이나 힘든 결 단을 요구하는 것이다. 자신에게 주어진 이름에 대한 불만은 그러한 이름을 지어준 부모에 대한 태도와도 관련이 깊다. 그러나 부모에 대한 긍정적인 경험 및 태도를 지닌 사람이 라면 부득이하게 가명을 사용할 수밖에 없는 상황에 부닥쳤 을 때, 자신의 성씨까지는 아니더라도 이름만은 바꿀 수 있 다. 그런 점에서 자발적인 동기로 성씨를 개명하는 것은 그 자신이 인식하지 못하는 강한 무의식적 동기에서 비롯된 행 위로 볼 수 있다. 호랑이는 죽어서 가죽을 남기고 사람은 죽 어서 이름을 남긴다는 옛말은 그만큼 이름의 소중함을 강조 한 말이다.

\section{Conflicts of Interest}

The author has no financial conflicts of interest.

\section{REFERENCES}

Abrams S. On discovering mother has a first name. Psychoanal Q 1982; 51:426-427.

Carotenuto A. A secret symmetry. Sabina Spielrein between Jung and Freud. London: Routledge \& Keegan Paul;1984.

Carty TJ. A dictionary of literary pseudonyms in the English language.
London: Mansell;2000.

Erikson EH. The problem of ego identity. J Am Psychoanal Assoc 1956; 4:56-121.

Freud S. An autobiographical study. Standard edition, Vol.20. London: Hogarth Press; 1925 . p.3-74.

Freud S. Family Romance. Standard edition, Vol.9. London: Hogarth Press; 1909. p.235-244

Freud S. Introductory lectures on psycho-analysis. Standard edition, Vol.15. London: Hogarth Press;1917. p.74-114.

Freud S. Jokes and Their Relation to the Unconscious. Standard edition, Vol.8. London: Hogarth Press;1905. p.42-91.

Freud S. The psychopathology of everyday life. Standard edition, Vol.6. London: Hogarth Press; 1901. p.83-225.

Freud S. Totem and Taboo. Standard edition, Vol.13. London: Hogarth Press;1913. p.56-113.

Gay P. A godless jew: Freud, Atheism, and the making of psychoanalysis. New Haven: Yale University Press; 1987.

Jeong WH. Name Changing. Seoul: Hakminsa;1994.

Joo MC. The writers who went to the hell. Goyang: Sonamu;1998.

Kaplan J, Bernays A. The language of names: what we call ourselves and why it matters. New York: Touchstone; 1999.

Kerr J. A most dangerous method: the story of Jung, Freud, and Sabina Spielrein. New York: Knopf;1993.

Lacan J. Ecrits. New York: WW Norton \& Co;2006.

Lee BK. Antisocial society. Psychoanalysis 2005a;16:67-81.

Lee BK. Identity crisis of jewish writers. Psychoanalysis 2005b;16:93100.

Lee BK. Psychoanalytic note on the death of Prince Sado. Psychoanalysis $2004 ; 15: 228-238$.

Meyer MA. The significance of an alteration of name. Int J Psychoanal 1923;4:484-485.

Murphy WF. A note on the significance of names. Psychoanal Q 1957; 26:91-106.

Noll R. The Aryan Christ: the secret life of Carl Jung. New York: Random House; 1997.

Noll R. The Jung Cult: origins of a charismatic movement. Princeton: Princeton University Press; 1994.

Oberndorf CP. Reaction to personal names. Int J Psychoanal 1920;1: 223-230.

Room A. A dictionary of pseudonyms and their origins, with stories of name changes. Jefferson, NC: McFarland;1998.

Sharpe EF. A note on 'The magic of names'. Int J Psychoanal 1946;27: 152.

Strean HS. The patient who would not tell his name. Psychoanal Q 1984;53:410-420.

Turkle S. Life on the screen: identity in the age of the internet. New York: Simon \& Schuster;1997.

Yi MY. An Anonymous Island. Seoul: Moonhaksasangsa;1988. 